\title{
Ocular Dermoid
}

National Cancer Institute

\section{Source}

National Cancer Institute. Ocular Dermoid. NCI Thesaurus. Code C161547.

Choristomatous tissue arising from an ectodermal anlage. 